\title{
Ramy prawne UE na rzecz umacniania praworządności. Uwagi na tle wniosku Komisji Europejskiej z 20 grudnia 2017 r.
}

\section{The European Union's Legal Framework for Strengthening the Rule of Law: Comments on the European Commission's Proposal of 20 December 2017}

The reasoned proposal submitted on 20 December 2017 to the Council by the European Commission on the rule of law in Poland is the first to launch a procedure for the protection of European Union's (EU) values. It was preceded by two-year activities of the European Commission aimed at establishing a dialogue between the Polish government and the EU regarding the basic problems, such as judicial independence and independent constitutional control.

The purpose of the article is to present the EU's legal framework whose goal is to strengthen the rule of law. Measures taken by the European Commission must be analysed from the perspective of the treaty framework and international legal obligations of the EU member states. The current political discourse often has a legal background. The study is based on the analysis of legal documents.

Keywords: rule of law, Article 7 TEU, judicial independence, political dialogue.

\section{Wprowadzenie}

Od prawie trzech lat Komisja Europejska podejmuje działania, które - w jej ocenie - mają prowadzić do obrony praworządności w Polsce. W związku z tym od listopada 2015 r. Komisja analizowała sytuację w Polsce oraz prowadziła dialog z rządem polskim. Rezultaty tych analiz oraz efekty dialogu były przedstawiane w kolejnych zaleceniach Komisji w sprawie praworządności kierowanych do Polski: z 27 lipca 2016 r. ${ }^{1}$, z 21 grudnia 2016 r. , z 26 lipca

1 Zalecenie Komisji (UE) 2016/1374 z 27 lipca 2016 r. w sprawie praworządności w Polsce, Dz. Urz. L 217 z 12.8.2016 r., s. 53.

2 Zalecenie Komisji (UE) 2017/146 z 21 grudnia 2016 r. w sprawie praworządności w Polsce uzupełniające zalecenie (UE) 2016/1374, Dz. Urz. L 22 z 27.01.2017 r., s. 65. 
$2017 \mathrm{r}^{3}$ oraz - ostatnie - z 20 grudnia $2017 \mathrm{r}$. $^{4} \mathrm{~W}$ wyniku przeprowadzonych działań 20 grudnia 2017 r. Komisja Europejska zdecydowała się skierować do Rady wniosek, w którym przedstawiła uzasadnienie oraz projekt decyzji Rady w sprawie stwierdzenia wyraźnego ryzyka poważnego naruszenia przez Rzeczpospolitą Polską zasady praworządności ${ }^{5}$. Komisja przedstawiła uzasadnienie swojego wniosku, opierając się na działaniach, które prowadziła na podstawie procedury określonej w przedstawionym w 2014 r. Komunikacie, skierowanym do Parlamentu Europejskiego i Rady, zatytułowanym „Nowe ramy UE na rzecz umocnienia praworządności”6. Z kolei 1 marca 2018 r. Parlament Europejski przyjął rezolucję, w której z zadowoleniem przyjęto decyzję Komisji o zastosowaniu art. 7 ust. 1 TUE w związku z sytuacją w Polsce 7.

Celem artykułu jest przedstawienie ram prawnych, w których działa Komisja Europejska. Środki podejmowane przez Komisję muszą być analizowane z perspektywy ram traktatowych oraz zobowiązań prawnomiędzynarodowych państw członkowskich UE. Za niewystarczający do zrozumienia istoty problematyki należy uznać dotychczasowy dyskurs polityczny, często odchodzący od przepisów prawa, które powinny stanowić bazę dla rozważań. Wyjaśnienia wymaga zatem w szczególności podstawa prawna do działań Komisji, co zostanie przeprowadzone na podstawie analizy dokumentów prawnych. Należy też podkreślić, że celem autora nie jest ocena efektów działań Komisji i zasadność jej wniosków ${ }^{8}$, jednak nie sposób nie odnieść się w tym kontekście i nie przywołać chociażby stanowisk innych organizacji i organów międzynarodowych.

3 Zalecenie Komisji (UE) 2017/1520 z 26 lipca 2017 r. w sprawie praworządności w Polsce uzupełniające zalecenie (UE) 2016/1374 i (UE) 2017/146, Dz. Urz. L 228 z 2.09.2017 r., s. 19.

4 Commission Recommendation of 20.12.2017 regarding the rule of law in Poland complementary to Commission Recommendations (EU) 2016/1374, (EU) 2017/146 and (EU) 2017/1520, dokument C(2017) 9050 final.

$5 \operatorname{COM}(2017) 838$ final, 20.12.2017 r.

$6 \operatorname{COM}(2014) 158$ final, 11.03.2014 r. Zob. dyskusję na temat poprawności zastosowanego pojęcia „praworządność”: T. Würtenberg, J.W. Tkaczyński, Nowe ramy Unii Europejskiej na rzecz umocnienia praworządności (analiza krytyczna), „Państwo i Prawo” 2017, nr 9, s. 16 oraz P. Marcisz, M. Taborowski, Nowe ramy Unii Europejskiej na rzecz umocnienia praworządności Krytyczna analiza analizy krytycznej (artykut polemiczny), „Państwo i Prawo” 2017, nr 12, s. 100.

7 2018/2541(RSP).

8 Na ten temat szerzej zob. chociażby M. Matczak, The Strength of the Attack or the Weakness of the Defence? Poland's Rule of Law Crisis and Legal Formalism, DOI:10.2139/ ssrn.3121611; L. Garlicki, Die Ausschaltung des Verfassungsgerichtshofes in Polen? (Disabling the Constitutional Court in Poland?), w: A. Szmyt, B. Banaszak (red.), Transformation of Law Systems in Central, Eastern and Southeastern Europe in 1989-2015, Gdańsk University Press, Gdańsk 2016, s. 63 i nast.; E. Łętowska, Zmierzch liberalnego państwa prawa w Polsce, „Kwartalnik o Prawach Człowieka” 2017, nr 1-2; M. Wyrzykowski, ,Wrogie przejęcie” porządku konstytucyjnego, w: M. Bernat i in. (red.), 


\section{Pojęcie „praworządności” w ujęciu Komisji Europejskiej}

Rozważania należy rozpocząć od wskazania, że w dokumentach Komisji pojawia się pewien problem terminologiczny, który dla niektórych staje się powodem do krytyki prac Komisji ${ }^{9}$. Mianowicie, jak wskazują niektórzy autorzy, należy mieć na uwadze, że termin „praworządność” nie jest tożsamy z pojęciem „państwa prawnego" ${ }^{10}$. Krytyka ta jest nieuzasadniona. Należy bowiem krótko przypomnieć, że - po pierwsze - wszystkie wersje językowe traktatów są jednakowo autentyczne. Nie można zatem zasadnie twierdzić, że bardziej właściwa jest jedna wersja językowa (np. niemiecka) i na niej należy się wzorować, stosując określoną terminologię. Trybunał Sprawiedliwości w swoich interpretacjach wielokrotnie podkreślał konieczność uwzględnienia wszystkich wersji językowych i wypracowywał własną, autonomiczną wykładnię konkretnych pojęć. Istotnie jednak w tytule dokumentu, który jest podstawą do działań Komisji Europejskiej, a mianowicie Komunikatu z 2014 r. „Nowe ramy UE na rzecz umocnienia praworządności”, posłużono się pojęciem odmiennym od tego, które występuje w polskiej wersji językowej art. 2 TUE ${ }^{11}$. Właściwsze byłoby więc użycie terminu zbieżnego z zastosowanym w art. 2 TUE, a zatem „państwa prawnego”. Bez względu

Wyzwania dla ochrony konkurencji i regulacji rynku, C.H. Beck, Warszawa 2017; L. Pech, S. Platon, Systemic Threats to the Rule of Law in Poland: Between Action and Procrastination, „European Issues” 2017, nr 451 czy A. Grzelak, Główne problemy naruszenia zasady praworzadności w Polsce podniesione przez Komisję Europejska, w: J. Barcz, A. Zawidzka-Łojek (red.), Wniosek Komisji Europejskiej w sprawie wszczęcia w stosunku do Polski procedury art. 7 TUE, Dom Wydawniczy Elipsa, Warszawa 2018, s. 57-73.

9 T. Würtenberger, J. Tkaczyński, Nowe..., s. 16.

10 Ibidem. Zob. również P. Marcisz, M. Taborowski, Nowe..., s. 100 oraz P. Bogdanowicz, Pojęcie, treść i ochrona praworzadności w prawie Unii Europejskiej, w: J. Barcz, A. Zawidzka-Łojek (red.), Wniosek..., s. 24. Warto również dodać, że sama Komisja Wenecka w sprawozdaniu z $2011 \mathrm{r}$. dostrzega różnice w terminologii, co jednak nie stoi na przeszkodzie podjęciu próby wypracowania takiej definicji, która będzie akceptowalna w każdych okolicznościach: „Although the terminology is similar, it is important to note at the outset that the notion of «Rule of law» is not always synonymous with that of «Rechtsstaat», «Estado de Direito» or «Etat de droit» (or the term employed by the Council of Europe: «prééminence du droit»). Nor is it synonymous with the Russian notion of «Rule of the laws/of the statutes», (verkhovenstvo zakona), nor with the term "pravovoe gosudarstvo» («law governed state») [...] This report aims to reconcile the above notions, and especially the notions of «Rule of Law», «Rechtsstaat» and «Etat de droit»". Zob. sprawozdanie Komisji Weneckiej z 4 kwietnia 2011 r., 512/2009, CDL-AD(2011)003 r.v.

11 Pojęcie praworządności, a nie państwa prawnego jest stosowane również w polskich wersjach językowych aktów prawa pochodnego UE, $\mathrm{np}$. w preambule rozporządzenia Parlamentu Europejskiego i Rady (UE) nr 233/2014 z 11 marca 2014 r. ustanawiające Instrument Finansowania Współpracy na rzecz Rozwoju na lata 2014-2020, Dz. Urz. UE L 77 z 15.03.2014, s. 44. 
jednak na tę różnicę, okoliczność ta nie ma w ogóle znaczenia dla ustalenia obowiązków państw wynikających z art. 2 TUE. Również ze względów powszechnego użycia pojęcia praworządności w dotychczasowej literaturze tematu oraz w dokumentach Komisji dotyczących omawianej kwestii, termin ten będzie używany w dalszej części artykułu.

Sama zasada praworządności jest uznawana za zasadę konstytucyjną działania wszystkich instytucji UE i jej państw członkowskich ${ }^{12}$. Chociaż w TUE nie zdefiniowano jej treści, zasada ta w ostatnich latach rozwoju integracji europejskiej objawiła się jako pojęcie centralne w działaniach UE (wcześniej WE) przede wszystkim jako wartość, na której UE jest zbudowana. W drugiej kolejności zasada praworządności jest warunkiem wzajemnego zaufania w działalności wspólnego rynku, a w szczególności w ramach przestrzeni wolności, bezpieczeństwa i sprawiedliwości, ponadto jest kryterium uzyskania członkostwa w UE, a wreszcie - centralnym elementem stosunków zewnętrznych UE, o czym dalej będzie jeszcze mowa.

Skoro jednak w TUE nie zdefiniowano tego pojęcia, można zastanawiać się, jak wyznaczyć jego treść i czy w ogóle jest potrzeba, by istniała jedna, wyczerpująca definicja tego terminu. W załączniku do Komunikatu z 2014 r. Komisja podkreśla, że zasada nie została zdefiniowana $\mathrm{w}$ żadnym systemie prawnym w sposób wyczerpujący. Odwołując się jednak do orzecznictwa Trybunału Sprawiedliwości (TS), począwszy od sprawy Les Verts ${ }^{13}$, Komisja wylicza główne zasady „godne odnotowania” w sposób, który nie ma absolutnie charakteru wyczerpującego. Do tych zasad zalicza się zasadę legalności, pewności prawa, zakaz arbitralności w działaniu władz wykonawczych, niezależność sądów, skuteczną kontrolę sądową czy równość wobec prawa. Zasady te są podstawowym

12 J.H.H. Weiler, The Rule of Law as Constitutional Principle of the European Union, ,Jean Monnet Working Paper" 2009, nr 4, http://jeanmonnetprogram.org/wp-content/uploads/2014/12/090401.pdf (dostęp: 21.03.2018).

13 Wyrok TS w sprawie C-294/83 w sprawie Les Verts przeciwko Parlamentowi Europejskiemu, Zb. Orz. z 1986 r., s. 1339. Zob. również wyrok TS z 2004 r. w sprawie C-496/99

Komisja przeciwko CAS Succhi di Frutta, Zb. Orz. z 2004 r., s. I-03801, pkt 63; wyrok z 1981 r. w sprawach połączonych 212 do 217/80 Amministrazione delle Finanze przeciwko Salumi, Zb. Orz. z 1981 r., s. 2735, pkt 10; wyrok z 1989 r. w sprawach połączonych 46/87 i 227/88 Hoechst przeciwko Komisji, Zb. Orz. z 1989 r., s. 02859, pkt 19; wyrok w sprawie C-583/11 P Inuit Tapiriit Kanatami i in. przeciwko Parlamentowi i Radzie, niepubl. w Zb. Orz., pkt 91; wyrok z 2010 r. w sprawie C-550/09 E i F, Zb. Orz. s. I-06213, pkt 44; wyrok z 2002 r. w sprawie C-50/00 P Unión de Pequeños Agricultores, Zb. Orz. s. I-06677, pkt 38 i 39; wyrok z 2000 r. w sprawach połączonych C-174/98 P i C-189/98 P, Niderlandy i van der Wal przeciwko Komisji, Zb. Orz. s. I-00001, pkt 17, wyrok z 2010 r. w sprawie C-279/09 DEB, Zb.Orz s. I-13849, pkt. 58 oraz wyrok z 2010 r. w sprawie C-550/07 P Akzo Nobel Chemicals Ltd i Akcros Chemicals Ltd przeciwko Komisji Europejskiej, Zb.Orz. s. I-08301, pkt 54. 
narzędziem służącym przestrzeganiu i poszanowaniu zasad demokracji i praw człowieka, a samo poszanowanie praworządności jest nierozerwalnie związane z poszanowaniem zasad demokracji i praw podstawowych.

W kontekście sytuacji Polski warto odnieść się do jednego z punktów, mającego szczególne znaczenie w związku z zarzutami stawianymi Polsce przez Komisję ${ }^{14}$. Odnosząc się do niezależności i skutecznej kontroli sądowej, Komisja odwołała się bowiem do tych orzeczeń TS, w których uściślano, że podmioty prywatne muszą mieść możliwość korzystania ze skutecznej ochrony sądowej swoich praw, a prawo do takiej ochrony stanowi część ogólnych zasad prawa, wynikających ze wspólnych tradycji konstytucyjnych państw członkowskich $^{15}$. Komisja w 2014 r. przypomniała także, iż Trybunał wyraźnie stwierdził, że ogólna zasada prawa UE, zgodnie z którą każda osoba ma prawo do rzetelnego procesu sądowego, inspirowana jest przez art. 6 Konwencji o ochronie praw człowieka i podstawowych wolności (EKPCz) i obejmuje prawo do sądu, przy czym sąd ten ma być niezależny - w szczególności od władzy wykonawczej. Uwzględniając różne modele i zróżnicowany zakres stosowania zasady na poziomie krajowym, TS wyraźnie podkreślił jednak konieczność wykonywania wszystkich funkcji z poszanowaniem zasady rozdzielności władz, charakteryzującej funkcjonowanie państwa prawa. Niezależnie od uzasadnienia Komisji warto w tym miejscu przypomnieć, że zasada niezależności sądów i niezawisłości sędziów jako element zasady rządów prawa jest przywoływana i analizowana, a także stanowi standard wynikający z aktów prawnych i dokumentów nie tylko Unii Europejskiej, lecz również Rady Europy czy ONZ ${ }^{16}$. Komisja nie unikała również odniesień do dorobku Rady Europy, a w szczególności Komisji Weneckiej. To w opracowaniach Komisji Weneckiej podkreśla się bliski związek zasady praworządności z prawami człowieka, w szczególności z perspektywy celu wspólnego, jakim jest ograniczenie potencjalnie nieograniczonej władzy państwa ${ }^{17}$. Działania zmierzające do wyznaczenia zakresu pojęcia, podejmowane przez Komisję Wenecką, która jest organem doradczym Rady Europy, znajdują swoje umocowanie w szczególności w przepisach Statutu Rady Europy, gdzie w preambule wymienia się praworządność jako podstawę każdej demokracji. Stąd też już

14 Szerzej na ten temat zob. A. Grzelak, Gtówne..., s. 58 i nast.

15 Zob. wyrok TS w sprawie C-583/11P Innuit Tapiriit Kanatami i n. przeciwko Parlamentowi i Radzie; wyrok w sprawie C-550/09 E i F czy wyrok w sprawie C-50/00P Union de Pequenos Agricultores.

16 Szerzej na ten temat zob. A. Grzelak, Gtówne..., s. 63.

17 Komisja Wenecka, Rule of Law Checklist, przyjęta na 106. Sesji Plenarnej (11-12 marca 2016 r.), CDL-AD(2016)007, par. 35, s. 9. 
w 2011 r. Komisja Wenecka opublikowała sprawozdanie, w którym wspominano o praworządności jako ,podstawowej i wspólnej normie europejskiej, która kieruje wykonywaniem uprawnień demokratycznych i ogranicza sposób ich wykonywania", w którym wymienia wspólne cechy praworządności, a wśród nich dostęp do sprawiedliwości przed niezależnymi i bezstronnymi sądami ${ }^{18}$.

Czy zatem można się spodziewać, że pojęcie praworządności zostanie ujednolicone, a od państw członkowskich UE będzie się wymagało zastosowania jednakowych rozwiązań konstytucyjnych tak, by można było mówić o jednolitym stosowaniu zasady? Sama Komisja Europejska nie spodziewa się takich działań ze strony państw członkowskich. Podkreśla wyraźnie, że „dokładna treść zasad i norm wynikających z praworządności może się różnić na poziomie krajowym w zależności od systemu konstytucyjnego państwa członkowskiego"19. Nie wydaje się, jak sugerują niektórzy autorzy, by w ogóle taka próba unifikacji prawnej wewnątrz Unii była potrzebna czy nawet możliwa ${ }^{20}$ - sposób realizacji podstawowych zasad wchodzących w zakres pojęcia praworządności musi być odnoszony indywidualnie nie tylko w stosunku do przepisów prawnych obowiązujących w danym państwie, ale również do praktyki ich stosowania i kultury prawnej i politycznej danego państwa ${ }^{21}$. Trzeba również podkreślić, że do wszczęcia procedury, o której mowa w art. 7 TUE, kluczowe znaczenie ma nie jednorazowe naruszenie zasady praworządności, lecz przypadek, gdy „organy państwa członkowskiego będą przyjmować środki lub tolerować sytuacje, które mogą mieć systematyczny negatywny wpływ na integralność, stabilność lub prawidłowe działanie instytucji i mechanizmów ochronnych ustanowionych na szczeblu krajowym w celu zapewnienia praworządności"22.

\section{Treść art. 7 TUE i przyczyny wprowadzenia tego przepisu do TUE}

To stanowisko Komisji Europejskiej, poparte orzecznictwem Trybunału Sprawiedliwości UE, a przede wszystkim odwołanie się w Traktacie o Unii

18 Zob.sprawozdanie KomisjiWeneckiejz4kwietnia2011 r.,512/2009, CDL-AD(2011)003 r.v. $19 \operatorname{COM}(2014) 158$ final, s. 4.

20 Zob. T. Wurtenberg J.W. Tkaczyński, Nowe..., s. 18.

21 Na przykład w trakcie dyskusji nad zmianami w sądownictwie twierdzono, że sędziów Sądu Najwyższego w Holandii wybiera parlament holenderski, co ma być argumentem za przyjęciem podobnych rozwiązań w Polsce. Jednak jak się okazuje, kandydatów wskazuje sam Sąd Najwyższy, a kultura prawna i praktyka stosowana tych przepisów prowadzi do sytuacji, w której parlament nigdy nie odmówił nominacji kandydatów wskazanych przez SN. Por. www.volkskrant.nl/buitenland/worden-in-andere-landen-ook-rechtersdoor-politici-benoemd-zoals-polen-beweert-nou-nee a4507601 (dostęp: 22.03.2018).

$22 \operatorname{COM}(2014) 158$ final. 
Europejskiej do zasady państwa prawnego, wyraźnie wskazuje, że Unia Europejska już dawno przestała być tylko wspólnotą ekonomiczną. Podkreśla to wyraźnie treść art. 2 TUE i powiązanego z nim art. 7 TUE, o którego zastosowanie wnioskuje Komisja Europejska w stosunku do Polski.

W dyskusji nad stosowaniem art. 7 TUE zapomina się dziś o tym, że genezy jego należy się doszukiwać w procesie ogromnego rozszerzenia Unii Europejskiej o dziesięć, a następnie o kolejne państwa głównie z Europy Środkowo-Wschodniej. W toku realizacji największego rozszerzenia UE jednoznacznie wskazano, że oprócz przygotowania ekonomicznego przesłanką uzyskania członkostwa w UE musi być spełnienie warunków politycznych, w tym przestrzeganie zasad demokratycznego państwa prawnego (tzw. kryteria kopenhaskie) $)^{23}$. Sama procedura uregulowana w art. 7 TUE była zatem efektem prac nad Traktatem z Amsterdamu, podczas których wyrażano obawy dotyczące zdolności „nowych” państw członkowskich do przestrzegania podstawowych zasad demokratycznego państwa prawnego. Obawy te znalazły swój wyraz we wprowadzeniu do TUE właśnie art. 7 w brzmieniu zbieżnym z obecnymi postanowieniami art. 7 ust. 2-5 TUE, jednak z pewnymi różnicami co do niektórych aspektów procedury. Wprowadzona przez Traktat z Amsterdamu procedura była jednak trudna do przeprowadzenia, gdyż ograniczała się wyłącznie do możliwości stwierdzenia „poważnego i stałego” naruszenia przez państwo członkowskie praworządności, z czym wiązała się możliwość zastosowania wyłącznie bardzo poważnej sankcji zawierzenia niektórych praw wynikających z traktatów. Problem ten unaocznił się w pełni na przełomie lat 1999/2000, w związku z sytuacją polityczną w Austrii i dojściem do władzy Jörga Haidera. Mimo ostrej reakcji pozostałych państw członkowskich UE, nie zdecydowano się wówczas na uruchomienie już obowiązującej procedury art. 7 TUE $^{24}$. Wpłynęło to jednak na decyzje Konferencji Międzyrządowej, która pracowała wówczas nad postanowieniami przyszłego Traktatu z Lizbony. W wyniku dyskusji zdecydowano się uzupełnić art. 7 TUE o zapis dotyczący mechanizmu monitorowania i wczesnego ostrzegania w przypadku, gdyby w jednym z państw członkowskich UE wystąpiła sytu-

23 J. Barcz, Ustrój lizbońskiej Unii Europejskiej. Podstawy traktatowe, struktura, instytucje i prawo, wyd. 2, Wszechnica IJM, Piaseczno 2017, s. 88 oraz s. 91.

24 Państwa członkowskie UE uzgodniły jednak na początku 2000 r. nałożenie na Austrię sankcji politycznych o charakterze dwustronnym. Zob. M. Happold, Fourteen Against One: The EU Member States Response to Freedom Party Participation in the Austrian Government, „International and Comparative Law Quarterly” 2000, vol. 49, nr 4, s. 953 Zob. też W. Sadurski, Adding Bite to Bark: The Story of Article 7, EU Enlargement, and Jörg Heider, „Columbia Journal of European Law” 2010, nr 16, s. 385 i nast. 
acja zagrażająca dochowaniu zasad wynikających z ówczesnego art. 6 ust. 1 TUE. W ten sposób doszło do wypracowania brzmienia art. 7 TUE, który nie został już zmieniony w Trakcie z Lizbony.

Jednocześnie jednak $\mathrm{W}$ związku $\mathrm{z}$ planami przekształcenia Unii Europejskiej w spójną organizację międzynarodową oraz pogłębieniem integracji europejskiej, dotykającym bezpośrednio obywateli i podmioty gospodarcze, ujawniła się konieczność sprecyzowania wspólnej aksjologii UE. W Traktacie ustanawiajacym Konstytucję dla Europy zaproponowano, a $\mathrm{w}$ Traktacie $\mathrm{z}$ Lizbony przejęto ideę wprowadzenia w motywie 2 preambuły do TUE wskazania, że państwo prawne było wymienione jako wartość będąca podstawą ustanowienia Unii Europejskiej wynikająca z dziedzictwa Europy. Trzeba przy tym przypomnieć, że kwestia ta nie była przedmiotem kontrowersji czy dyskusji25. Dodatkowo w Traktacie o Unii Europejskiej przejęto też z Traktatu konstytucyjnego art. I-2 określający „Wartości Unii”, stwierdzając $w$ art. 2 TUE, iż „Unia opiera się na wartościach poszanowania godności osoby ludzkiej, wolności, demokracji, równości, państwa prawnego, jak również poszanowania praw człowieka, w tym praw osób należących do mniejszości. Wartości te są wspólne Państwom Członkowskim w społeczeństwie opartym na pluralizmie, niedyskryminacji, tolerancji, sprawiedliwości, solidarności oraz na równości kobiet i mężczyzn”. Przepis ten nie ma charakteru wyłącznie symbolicznego. Ma istotne znaczenie nie tylko polityczne, lecz przede wszystkim normatywne. Stanowi punkt odniesienia do weryfikacji przestrzegania przez państwa członkowskie tych zasad $\mathrm{w}$ procedurze uregulowanej w art. 7 TUE, a dodatkowo jest podstawą kwalifikacji państwa jako nowego państwa członkowskiego UE (art. 49 TUE).

Jeżeli zatem państwo członkowskie UE nie przestrzega wartości z art. 2 TUE, to wówczas - w świetle art. 7 TUE - możliwe jest przeprowadzenie procedury oceny politycznej przez państwa członkowskie (w ramach Rady lub Rady Europejskiej), czy naruszone zostały standardy państwa prawnego, o których mowa w art. 2 TUE. Na mechanizm art. 7 TUE składają się trzy etapy, przy czym nie muszą one być łącznie wykorzystywane. Istnieje mechanizm prewencyjny (art. 7 ust. 1 TUE), mechanizm prowadzący do stwierdzenia naruszenia (art. 7 ust. 2 TUE) oraz mechanizm sankcyjny (art. 7 ust. 3 TUE) ${ }^{26}$. W pierwszym etapie Rada UE może stwierdzić „,wy-

25 W przeciwieństwie do odesłania do religii jako wspólnego elementu dziedzictwa Europy. Zob. J. Barcz, Ustrój..., s. 88.

26 Zob. komentarz P. Filipka do art. 7 TUE, w: K. Lankosz (red.), Traktat o Unii Europejskiej. Komentarz, C.H. Beck, Warszawa 2003, s. 142. 
raźne ryzyko poważnego naruszenia" wartości określonych w art. 2 TUE, w tym praworządności. W takim przypadku Rada może wydać stosowne zalecenia dla państwa ${ }^{27}$. Na tym etapie konieczne jest uzyskanie w Radzie większości 4/5 głosów, liczonych oczywiście bez tego, któremu zarzuca się naruszenie. W tej sprawie zgodę musi wyrazić również Parlament Europejski, większością 2/3 oddanych głosów (art. 354 ak. 4 TFUE). W drugiej fazie do głosu dochodzi Rada Europejska, która może jednomyślnie i za zgodą Parlamentu Europejskiego stwierdzić poważne i stałe naruszenie wartości określonych w art. 2 TUE. Wreszcie Rada może zdecydować o zawieszeniu niektórych praw wynikających ze stosowania traktatów wobec naruszającego państwa członkowskiego. Ta możliwość nazywana jest potocznie i publicystycznie „opcją nuklearną”. Warto przy tym zwrócić uwagę, że nie ma możliwości zawieszenia wszelkiego rodzaju praw, a tylko niektóre - nie można zatem rozpatrywać jako sankcji wykluczenia państwa członkowskiego z UE. Wybór praw, które mają zostać zawieszone, należy do Rady i można sobie w tym kontekście wyobrazić np. zawieszenie wypłaty funduszy unijnych czy też zawieszenie możliwości udziału kandydatów danego państwa w określonych organach ${ }^{28}$.

$\mathrm{Na}$ marginesie warto dodać, że mechanizm oceny przestrzegania praworządności nie jest właściwy tylko dla Unii Europejskiej. Zgodnie z art. 8 Statutu Rady Europy, państwo, które poważnie naruszyło zasady praworządności i prawa człowieka, może zostać zawieszone w swym prawie reprezentacji, a nawet wykluczone z Rady Europy. $Z$ mechanizmu tego do tej pory nie skorzystano $^{29}$, chociaż były przypadki zawieszenia praw delegacji w pracach Zgromadzenia Parlamentarnego Rady Europy, których podstawą prawną nie był jednak wprost art. 8 Statutu $^{30}$.

27 Dyskusyjne jest, czy Rada może zrobić to przed stwierdzeniem naruszenia (jak wskazuje brzmienie przepisu), czy także po tym (jak zdaje się uważać Komisja - por. wskazywany wniosek z 20 grudnia 2017 r.).

28 Bardziej szczegółowo całą procedurę opisał M. Taborowski, Aspekty proceduralne postępowania w sprawie praworządności wobec Polski, w: J. Barcz, A. Zawidzka-Łojek (red.), Wniosek..., s. 45 i nast.

29 Chociaż warto pamiętać, że po zamachu stanu w 1967 r. Grecja sama wystąpiła z Rady Europy na mocy art. 7 Statutu Rady Europy, wracając do niej ponownie w 1974 r.

30 Zgodnie z Regulaminem Proceduralnym Zgromadzenia pełnomocnictwa delegacji krajowego parlamentu mogą zostać zakwestionowane „ze względów zasadniczych”, jeśli w danym państwie dochodzi do „poważnego pogwałcenia podstawowych zasad Rady Europy” lub „ciągłego niewykonywania zobowiązań” (reguła 8.1 i 8.2). W ten sposób np. doszło do zawieszenia praw delegacji rosyjskiej w pracach Zgromadzenia Parlamentarnego Rady Europy w kwietniu 2014 r. oraz w styczniu 2015 r. 


\section{Kompetencje Komisji Europejskiej do prowadzenia działań wobec państw członkowskich}

Na fali wydarzeń, do jakich doszło we Francji czy na Węgrzech, gdzie pojawiły się problemy i wątpliwości co do zgodności działań rządów tych państw w kontekście zasad demokratycznego państwa prawnego, przewodniczący Komisji Europejskiej w swoim dorocznym orędziu o stanie UE w 2012 r. wskazał, że konieczne jest stworzenie „lepiej rozwiniętego wachlarza instrumentów - nie wystarczy już wybór między miękką władzą politycznej perswazji a radykalnym rozwiązaniem z art. 7 Traktatu"31. W kolejnym zaś roku potwierdził, że Komisja musi odgrywać rolę niezależnego i obiektywnego arbitra i zapowiedział przedstawienie komunikatu w tej sprawie przy założeniu, że kluczowym elementem procedury będzie możliwość prowadzenia dyskusjij ${ }^{32}$.

Ze względu na różne wypowiedzi dotyczące kompetencji Komisji Europejskiej do podejmowania działań w tej sprawie, warto pewne zagadnienia wyjaśnić, zwłaszcza poprzez odniesienie się do stosownych przepisów traktatowych.

Bez wątpienia wśród organów uprawnionych do wszczęcia procedury z art. 7 TUE jest Komisja Europejska (obok Parlamentu Europejskiego i 1/3 państw członkowskich). Komisja Europejska w 2014 r. uznała, że treść art. 7 TUE nie jest wystarczająca do przeprowadzenia postępowania, które zmierzałoby do złożenia przez nią właściwego wniosku. $Z$ tego względu w Komunikacie z 11 marca 2014 r. „Nowe ramy UE nakierowane na umocnienie zasady państwa prawa" sprecyzowała postępowanie (zw. nowymi ramami UE na rzecz umocnienia praworządności), które może prowadzić do przedłożenia przez Komisję Europejską takiego wniosku Radzie UE ${ }^{33}$.

Samo przygotowanie takiego komunikatu wzbudziło zastrzeżenia prawne w 2014 r. po stronie Służby Prawnej Rady. W jej opinii traktaty nie zapewniają żadnej podstawy prawnej, która uprawniałaby instytucje do stworzenia nowego mechanizmu nadzoru nad poszanowaniem praworządności przez państwa członkowskie, dodatkowo do zapisów w art. 7 TUE, ani też do zmiany, modyfikacji czy uzupełnienia procedury określonej w tym artykule ${ }^{34}$. Należy jednak zauważyć, że zasadniczo państwa członkowskie nie sprzeciwiły się

31 J. Barroso, Orędzie o stanie Unii w 2012 r., http://europa.eu/rapid/press-release_SPE-ECH-12-596_pl.htm (dostęp: 10.10.2016).

32 J. Barroso, Orędzie o stanie Unii w 2013 r., dostępne na stronie http://europa.eu/rapid/ press-release_SPE-ECH-13-684_pl.htm (dostęp: 10.10.2016).

$33 \operatorname{COM}(2014) 158$ final.

34 Opinia Służb Prawnych Rady 10296/14, 27 maja 2014 r. Warto dodać, że Rada nie wydała stanowiska jednoznacznie kwestionującego kompetencje Komisji w tej sprawie. 
sprecyzowaniu przez Komisję takiej procedury. Stanowisko Służby Prawnej Rady zostało też skrytykowane w literaturze ${ }^{35}$. Uważano, że celem procedury wszczynanej przez Komisję jest nakierowanie na wyjaśnienie sytuacji w danym państwie członkowskim, co ma wykluczyć potrzebę rozpoczynania procedury formalnej i umożliwić wywarcie wpływu politycznego.

Procedura przed Komisją Europejską przebiega w trzech etapach. Podczas pierwszego etapu Komisja Europejska prowadzi dialog polityczny z danym państwem członkowskim i dokonuje oceny, czy zachodzą w nim przesłanki wystąpienia „systemowego zagrożenia dla zasady państwa prawa”. W przypadku wątpliwości Komisja Europejska przedkłada opinię, oczekując od państwa uwag i wyjaśnień. Etap drugi rozpoczyna się wówczas, gdy wyjaśnienia i działania państwa nie są zadowalające. W takim przypadku Komisja Europejska przedkłada państwu zalecenia, w których konkretyzuje - co należy poprawić i w jakim terminie. Trzeci etap to moment, gdy w wyniku monitorowania sytuacji w danym państwie i po ocenie, że podejmowane przez państwo działania nie są odpowiednie, Komisja podejmuje decyzję o formalnym wszczęciu procedury z art. 7 TUE. Komisja podkreśliła przy tym, że postępowanie prowadzone przez nią na podstawie Komunikatu nie zastępuje procedury $z$ art. 7 TUE, lecz wyłącznie ją poprzedza i uzupełnia, a także pozostaje bez uszczerbku dla możliwości wykorzystania procedury z art. 258 TFUE.

Procedura „przedtraktatowa” ma zatem służyć przede wszystkim poszerzeniu możliwości oddziaływania na państwo członkowskie UE, bez konieczności wszczynania postępowania formalnego, co zawsze stawia państwo w trudnej politycznie sytuacji. Z Komunikatu Komisji przedstawionego w 2014 r. jasno wynikają dwa źródła decyzji o stworzeniu tego mechanizmu: po pierwsze art. 7 TUE, ale po drugie również art. 258 TFUE. Komisja przypomniała, że działania podejmowane przez nią na podstawie art. $258 \mathrm{TFUE}$ (procedura naruszenia przez państwo członkowskie zobowiązania wynikającego z traktatów) są instrumentem ważnym, jednak wiążą się z poważnymi ograniczeniami formalnymi. Komisja może wszcząć postępowanie na podstawie art. 258 TFUE wyłącznie wówczas, gdy problem naruszenia praworządności wiąże się bezpośrednio z naruszeniem konkretnego przepisu prawa $\mathrm{UE}^{36}$, czego przykładem może być postępowanie

35 Zob. np. D. Kochenov, L. Pech, Monitoring and Enforcement of the Rule of Law in the EU: Rhetoric and Reality, „European Constitutional Law Review” 2015, nr 3. Zob. też P. Marcisz, M. Taborowski, Nowe ramy..., s. 100 i nast.; M. Taborowski, Aspekty proceduralne..., s. 37.

36 Komisja przywołała jako ilustrację trzy sprawy: C-282/12 Komisja przeciwko Węgrom (ECLI:EU:C:2012:697), C-518/07 Komisja przeciwko Niemcom(ECLI:EU:C:2012:687) oraz C-614/10 Komisja przeciwko Austrii (ECLI:EU:C:2012:631). Szerzej na temat relacji między art. 258 TFUE a procedurą określoną w art. 7 TUE zob. P. Bogdanowicz, 
wszczęte przeciwko Polsce w sprawie C-192/1837. Tymczasem art. 7 TUE dotyczy sytuacji, w których zagrożenie dla państwa prawnego ma charakter systemowy.

Po wszczęciu przez Komisję Europejską procedury wobec Polski pojawiły się głosy kwestionujące prawo Komisji do uregulowania takiej procedury, z którymi jednakże nie sposób się zgodzić ${ }^{38}$. Trzeba stwierdzić przede wszystkim, że istota procedury opisanej w Komunikacie Komisji sprowadza się do działań, które mają wyjaśnić, czy istnieje uzasadnienie dla złożenia uzasadnionego wniosku przez Komisję. Takie uzasadnienie jest obowiązkowe, co wynika $z$ art. 7 ust. 1 TUE. Musi przy tym zawierać wszelkie informacje, które będą potwierdzały np. istnienie wyraźnego ryzyka poważnego naruszenia praworządności. Bez możliwości monitorowania sytuacji w danym kraju Komisja nie byłaby w stanie sformułować swojego uzasadnienia. Trzeba przy tym pamiętać, że ostateczna decyzja, czy przedstawione uzasadnienie ma swoje podstawy, nie będzie należeć do Komisji, lecz do Rady lub Rady Europejskiej. Wniosek Komisji sformułowany na ostatnim etapie procedury nie jest zatem ostateczną decyzją przesądzającą o istnieniu naruszenia praworządności w danym kraju. Działania Komisji muszą być zatem w jak największym stopniu zorientowane na ustalenie faktycznych przyczyn i skutków zagrożenia dla zasady praworządności w państwie członkowskim.

Komisja zgodnie z art. 17 TUE czuwa nad stosowaniem traktatów i jest tą instytucją, która w związku z powyższym jest uznana za właściwą również do oceny przestrzegania wartości UE wyrażonych w art. 2 TUE. Komisja ma również nieograniczone prawo do kierowania zaleceń, zgodnie z art. 292 TFUE. Zalecenia nie mają charakteru wiążącego. Obowiązek państwa do współdziałania w tym zakresie z Komisją ma zaś swoją wyraźną podstawę w art. 4 ust. 3 TUE - zasadzie lojalnej współpracy. Można zatem wręcz stwierdzić, że uregulowanie procedury w Komunikacie i poinformowanie o niej zainteresowane podmioty jest elementem nie tylko przejrzystości, ale i wręcz pewności prawa ${ }^{39}$.

Pojęcie..., s. 28 i nast. Zob. także P. Bogdanowicz, M. Taborowski, Brak niezależności sadów krajowych jako uchybienie zobowiąaniu w rozumieniu art. 258 TFUE (cz. I), „Europejski Przegląd Sądowy” 2018, nr 1.

37 K. Lenaerts, The Court of Justice and national courts: A dialogue based on mutual trust and judicial independence, wystąpienie w Naczelnym Sądzie Administracyjnym w Warszawie, 19 marca 2018, s. 8 (manuskrypt w posiadaniu autorki). Zob. też M. Taborowski, CJEU Opens the Door for the Commission to Reconsider Charges against Poland, Verfassungsblog, 2018/3/13, DOI: 10.17176/20180313-203040, par 2-3.

38 Przeciwstawia się im również M. Taborowski, Aspekty..., s. 43.

39 B. Grabowska-Moroz oraz M. Szuleka piszą o tym, że jedną z gwarancji rzetelności kontroli praworządności będzie zapewnienie jej jak największej transparentności. Zob. B. Grabowska-Moroz, M. Szuleka, Unijna procedura kontroli praworzadności-panaceum czy placebo?, Helsińska Fundacja Praw Człowieka, Warszawa 2016, s. 1. 
Po trzecie, warto wspomnieć, że analogiczna procedura wstępna, tzw. EU-Pilot, ma zastosowanie w przypadku procedury $\mathrm{z}$ art. 258 TFUE. Jest to nieformalny dialog między Komisją a państwem członkowskim w sprawie potencjalnego naruszenia zobowiązania traktatowego i jest prowadzona przed wszczęciem formalnej procedury. Państwa członkowskie i Komisja wymieniają informacje dotyczące szczegółów konkretnych spraw. W ramach tej procedury Komisja oczekuje na odpowiedź państwa członkowskiego w ciągu 10 tygodni, a następnie ma kolejne 10 tygodni na ocenę odpowiedzi. Jeżeli odpowiedź nie jest satysfakcjonująca, to wówczas oficjalnie wszczynana jest procedura z art. 258 TFUE. Ta procedura również nie została uregulowana traktatowo, a jednak jej funkcjonowania nikt nie kwestionuje, gdyż nie ma ona charakteru wiążącego. Analogiczna sytuacja jest z procedurą opisaną w Komunikacie Komisji z 2014 r.

Nawet zatem gdyby chcieć zakwestionować kompetencje Komisji do prowadzenia postępowania $\mathrm{w}$ sprawie praworządności (chociaż $\mathrm{z}$ formalnych względów jest to obecnie niemal niemożliwe ${ }^{40}$ ), to jednak i tak trzeba mieć świadomość, że Komisja będzie uprawniona do złożenia wniosku o wszczęcie procedury z art. 7 TUE. Komisja musi mieć dowolność odnośnie do sposobu przygotowania się do złożenia wniosku w tej sprawie. Warto też dodać, że Parlament Europejski legitymizuje działania Komisji Europejskiej, czego dowodem jest przegłosowana 1 marca 2018 r. rezolucja popierająca działania Komisji ${ }^{41}$, w której wezwał on Radę do podjęcia działań w tej sprawie.

\section{Sprawa polska}

Chociaż problemy, które zostały wskazane przez Komisję we wniosku skierowanym do Komisji, były już omówione w literaturze ${ }^{42}$, w celu uzyskania pełności wywodu należy w tym miejscu przypomnieć, że dla Komisji Europejskiej istotne są dwa podstawowe zagadnienia:

- po pierwsze - sytuacja Trybunału Konstytucyjnego w Polsce,

- po drugie - sytuacja sądów powszechnych oraz Sądu Najwyższego.

Jako zagadnienie podstawowe Komisja wskazuje na „brak niezależnej i zgodnej z prawem kontroli zgodności z Konstytucją"43. Dodatkowo wymienia

40 Por. M. Taborowski, Aspekty..., s. 44-45.

41 European Parliament resolution of 1 March 2018 on the Commission's decision to activate Article 7(1) TEU as regards the situation in Poland (2018/2541(RSP))

42 Przywoływane już opracowywania oraz np. P. Filipek, Challenges to the Rule of Law in the European Union: the distressing case of Poland, tekst złożony do publikacji w Revista do Instituto Brasileiro de Direitos Humanos (manuskrypt w posiadaniu autorki).

$43 \operatorname{COM}(2017) 835$ final, s. 1 oraz s. 16 i nast. 
przyjęcie przez polski parlament nowych przepisów ustawodawczych, „dotyczących systemu sądownictwa, które w jej ocenie budzą poważne obawy co do niezależności sądów i znacząco zwiększają systemowe zagrożenie praworządności w Polsce"44. Są to:

- ustawa z 8 grudnia 2017 r. o Sądzie Najwyższym ${ }^{45}$,

- ustawa z 12 lipca 2017 r. o zmianie ustawy - Prawo o ustroju sądów powszechnych ${ }^{46}$

- ustawa z 8 grudnia 2017 r. o zmianie ustawy o Krajowej Radzie Sądownictwa oraz niektórych innych ustaw ${ }^{47}$,

- ustawa z 11 maja 2017 r. o zmianie ustawy o Krajowej Szkole Sądownictwa i Prokuratury, ustawy - Prawo o ustroju sądów powszechnych oraz niektórych innych ustaw ${ }^{48}$.

To, co jest równie istotne i co należy przypomnieć w tym miejscu to fakt, że Komisja Europejska nie jest osamotniona w walce o zachowanie podstawowych wartości państwa prawnego w Polsce. Tylko od 31 lipca 2017 r. swoje bardzo krytyczne stanowiska przedstawili m.in.:

- Biuro Instytucji Demokratycznych i Praw Człowieka ODIHR z 30 sierpnia $2017 \mathrm{r}^{49}$;

- Rada Praw Człowieka ONZ w ramach trzeciego przeglądu okresowego dotyczącego Polski, zawarła zalecenia w sprawie niezależności sądów i praworządności (22 września 2017 r.) $)^{50}$;

- Zgromadzenie Parlamentarne Rady Europy w rezolucji z 11 października 2017 r. w sprawie nowych zagrożeń dla praworządności w krajach będących członkami Rady Europy, w której wyrażono również niepokój wydarzeniami w Polsce, a w szczególności ryzykiem dla niezależności sądów i podziału władz ${ }^{51}$,

- Specjalny Sprawozdawca ONZ ds. Niezawisłości Sędziów i Prawników z 22 grudnia 2017 r. $^{52}$,

44 Ibidem.

45 Dz. U. z 2018 r. poz. 5

46 Dz. U. z 2017 r. poz. 1452

47 Dz.U. z 2018 r. poz. 3

48 Dz. U. z 2017 r., poz. 1139

49 Opinia z 30 sierpnia 2017 r., Opinion on Certain Provisions of the Draft Act on the Supreme Court, www.osce.org/odihr/legislative-support (dostęp: 25.05.2018).

50 www.ohchr.org/EN/HRBodies/UPR/Pages/PLIndex.aspx (dostęp: 25.05.2018).

51 PACE, 11.10.2017 r., Rezolucja 2188(2017): „New threat to the rule of law in Council of Europe Member States: selected examples".

52 www.ohchr.org/EN/NewsEvents/Pages/DisplayNews.aspx?NewsID=22564\&LangI$\mathrm{D}=\mathrm{E}$ (dostęp: 25.05.2018). 
- Komisja Wenecka w opiniach przygotowanych na wniosek Zgromadzenia Parlamentarnego Rady Europy z 8 grudnia 2017 r. w sprawie: 1) projektu ustawy o Krajowej Radzie Sądownictwa, projektu ustawy o Sądzie Najwyższym i ustawy Prawo o ustroju sądów powszechnych oraz 2) ustawy - Prawo o prokuraturze ${ }^{53}$,

- Komisarz Praw Człowieka Rady Europy ostatnio w liście skierowanym do Prezesa Rady Ministrów Mateusza Morawieckiego z 19 stycznia 2018 r. ${ }^{54}$

To wyraźny dowód na to, że problemy zawarte we wniosku Komisji Europejskiej, stanowią przedmiot obaw wielu najważniejszych organizacji i podmiotów międzynarodowych oraz są wyrazem troski społeczności międzynarodowej. Nie można zatem twierdzić, jak czasem można usłyszeć w dyskursie politycznym, że stanowisko Komisji Europejskiej ma charakter nieuzasadniony, nieznaczący i odosobniony. Jednak poza istnieniem wskazywanych problemów, Komisja podkreśla jeszcze jedną bardzo ważną kwestię, a mianowicie brak współpracy z rządem polskim - w szczególności wytyka brak reakcji na zalecenia, brak właściwego wyjaśnienia sytuacji czy kompletne ignorowanie w szczególności opinii Komisji Weneckiej, będącej organem doradczym Rady Europy.

\section{Wnioski}

Wniosek skierowany przez Komisję Europejską w sprawie praworządności w Polsce jest pierwszym o uruchomienie procedury ochrony wartości UE wobec państwa członkowskiego. Został poprzedzony dwuletnimi działaniami Komisji Europejskiej nakierowanymi na nawiązanie dialogu, który zmierzać ma do położenia kresu działaniom, które w ocenie Komisji podważają przede wszystkim niezależność władzy sądowniczej, niezawisłość sędziowską, a przede wszystkim niezależną i zgodną z prawem kontrolę konstytucyjną. Toczącej się procedurze towarzyszy jednak dyskusja polityczna, która odbiega od realiów politycznych i świadczy albo o nieznajomości, albo o lekceważeniu reguł członkostwa państwa w UE oraz procedur traktatowych.

53 Opinia 904/2017 CDL(2017)035 Komisji Weneckiej w sprawie projektu ustawy o zmianie ustawy o Krajowej Radzie Sądownictwa i projektu ustawy o zmianie ustawy o Sądzie Najwyższym, zaproponowanych przez Prezydenta RP oraz w sprawie ustawy - Prawo o ustroju sądów powszechnych CDL(2017)035 oraz Opinia 892/2017 CDL(2017)037 Komisji Weneckiej w sprawie ustawy - Prawo o prokuraturze.

$54 \mathrm{https} / / / \mathrm{rm}$.coe.int/letter-to-mr-mateusz-morawiecki-prime-minister-of-the-republic-of-pola/1680784182 (dostęp: 25.05.2018). 
Jednocześnie dowodzi wyraźnie o umniejszaniu wagi międzynarodowych standardów ochrony praw człowieka.

Podsumowując rozważania, należy wyrazić nadzieję, iż przytoczone argumenty wyraźnie rozwiewają pojawiające się niekiedy głosy wskazujące na niezrozumienie funkcjonowania demokratycznego państwa prawnego w społeczności międzynarodowej, że działania Komisji Europejskiej podważają wyłączne kompetencje Polski i naruszają jej suwerenność. Wyłącznie ze względów ograniczeń formalnych niemożliwe było przypomnienie tych elementów, które potwierdzają, że sądy polskie są sądami unijnymi, a zasada wzajemnego zaufania jest podstawową wartością we współpracy organów wymiaru sprawiedliwości w UE. Dowodem na to jest chociażby ostatnio skierowane pytanie prejudycjalne sądu irlandzkiego w sprawie dotyczącej wykonania polskiego europejskiego nakazu aresztowania ${ }^{55}$ czy też stanowisko sędziów niemieckich, wyrażone w związku z sytuacją w Polsce ${ }^{56}$. Zgodnie z zasadami współczesnego prawa międzynarodowego państwo nie może powoływać się na swoje kompetencje wewnętrzne w celu uzasadnienia każdej prowadzonej przez władze państwowe działalności ${ }^{57}$.

Podnoszenie w debacie argumentów wskazujących na brak kompetencji Komisji do podejmowania działań poprzedzających złożenie wniosku na podstawie art. 7 TUE wydaje się w istocie mieć cel odciągnięcia uwagi i koncentracji na istocie problemu, a zatem na zagrożeniach dla praworządności w Polsce, które istnieją nie tylko w ocenie Komisji, ale również wielu innych organów międzynarodowych.

Nieakceptowalnym argumentem jest odwoływanie się do sytuacji innych państw i wskazywanie, że Komisja działa w sposób „niesprawiedliwy", prowadząc postępowanie wyłącznie wobec Polski. Do oceny sytuacji w Polsce nie ma to żadnego znaczenia. Faktem jest, że po wejściu w życie Traktatu z Lizbony „w zakresie zainteresowania” procedury art. 7 TUE były wymieniane zarówno „stare” państwa członkowskie (np. Francja w związku z programem likwidacji obozowisk romskich ${ }^{58}$ ), jak i „nowe” - Bułgaria,

55 Zob. doniesienia medialne w tej sprawie www.irishtimes.com/news/crime-and-law/courts/ high-court/high-court-judge-seeks-eu-ruling-on-effect-of-polish-law-changes-1.3424530 (dostęp: 22.03.2018).

56 www.rp.pl/Sedziowie-i-sady/303219917-Niemieccy-sedziowie-KE-nie-powinna-odpus cic-Polsce-ws-naruszenia-praworzadnosci.html (dostęp: 22.03.2018).

57 Szerzej na ten temat zob. J. Barcz, Podsumowanie i wnioski, w: J. Barcz, A. Zawidzka-Łojek (red.), Wniosek..., s. 74-75.

58 Zob. B. Grabowska-Moroz, M. Szuleka, Unijna..., s. 3. 
Rumunia, przede wszystkim zaś Węgry ${ }^{59}$, ale w efekcie jednak procedura została uruchomiona wobec Polski. Nawet jeżeli można zarzucać Komisji, że nie podejmuje działań wobec innych państw, to trzeba wyraźnie zaznaczyć, iż sytuacja innych państw i ich problemy nigdy nie mogą uzasadniać akceptacji łamania podstawowych zasad demokratycznego państwa prawnego.

Ponadto wskazywanie, że nie dojdzie do zastosowania art. 7 TUE, ponieważ do nałożenia sankcji konieczna jest jednomyślność w Radzie Europejskiej, też jest argumentem zwodniczym. Nie chodzi w tym postępowaniu o formalne zastosowanie sankcji, lecz o miejsce Polski w grupie państw członkowskich UE, o jej zdolności koalicyjne, o możliwość efektywnego udziału we współpracy międzynarodowej. Patrząc na obecną sytuację przez pryzmat przepisów traktatowych, nie wolno zapominać o skutkach politycznych. Kłopoty z praworządnością mogą być łatwo wykorzystywane do osłabienia pozycji państwa w ramach UE. Tu wyraźnie widać spadek pozycji Polski i brak zdolności negocjacyjnych, czego dowodem jest porażka w sprawach kluczowych, jak np. w sprawie pracowników delegowanych w $\mathrm{UE}^{60}$. Innym przykładem jest również nieprzyznanie Polsce żadnego miejsca w ramach niedawnego konkursu na stanowiska w Europejskiej Służbie Działań Zewnętrznych ${ }^{61}$. To tylko dwa przykłady, a przecież w najbliższym czasie będą podejmowane ważne decyzje w sprawie przyszłości Unii.

Wreszcie trzeba pamiętać, że głównym celem unijnej kontroli praworządności jest wypracowanie rozwiązań - nie samo karanie państwa, w którym wystąpiły problemy. Chodzi tu raczej o przypomnienie państwu o obowiązkach wynikających z samego członkostwa w UE.

\section{Bibliografia}

Barcz J., Ustrój lizbońskiej Unii Europejskiej. Podstawy traktatowe, struktura, instytucje i prawo, wyd. 2, Wszechnica IJM, Piaseczno 2017.

Barcz J., Zawidzka-Łojek A. (red.), Wniosek Komisji Europejskiej w sprawie wszczęcia procedury w stosunku do Polski procedury art. 7 TUE, Dom Wydawniczy Elipsa, Warszawa 2018.

59 M. Izdebski, Unijny mechanizm ochrony praworządności w państwach członkowskich, „Prawo Europejskie w Praktyce” 2016, nr 4, s. 9. Zob. też rezolucję Parlamentu Europejskiego z 3 lipca 2013 r. w sprawie sytuacji praw podstawowych: standardy i praktyki na Węgrzech, 2012/2130 (INI).

60 www.money.pl/gospodarka/wiadomosci/artykul/pracownicy-delegowani-ue-rafalska,236,0,2380524.html (dostęp: 21.03.2018).

61 www.wprost.pl/swiat/10108292/dyplomatyczna-porazka-polski-nasz-kraj-bez-nowychprzedstawicieli-w-delegaturach-ue.html (dostęp: 21.03.2018). 
Bogdanowicz P., Pojęcie, treść i ochrona praworządności w prawie Unii Europejskiej, w: J. Barcz, A. Zawidzka-Łojek (red.), Wniosek Komisji Europejskiej w sprawie wszczęcia w stosunku do Polski procedury art. 7 TUE, Dom Wydawniczy Elipsa, Warszawa 2018.

Bogdanowicz P., Taborowski M., Brak niezależności sądów krajowych jako uchybienie zobowiązaniu w rozumieniu art. 258 TFUE (cz. I), „Europejski Przegląd Sądowy” 2018, nr 1.

Garlicki L., Die Ausschaltung des Verfassungsgerichtshofes in Polen? (Disabling the Constitutional Court in Poland?), w: A. Szmyt, B. Banaszak (red.), Transformation of Law Systems in Central, Eastern and Southeastern Europe in 1989-2015, Gdańsk University Press, Gdańsk 2016.

Grabowska-Moroz B., Szuleka M., Unijna procedura kontroli praworządności-panaceum czy placebo?, Helsińska Fundacja Praw Człowieka, Warszawa 2016.

Grzelak A., Główne problemy naruszenia zasady praworządności w Polsce podniesione przez Komisję Europejska, w: J. Barcz, A. Zawidzka-Łojek (red.), Wniosek Komisji Europejskiej w sprawie wszczęcia $w$ stosunku do Polski procedury art. 7 TUE, Dom Wydawniczy Elipsa, Warszawa 2018.

Happold M., Fourteen Against One: the EU Member States' Response to Freedom Party Participation in the Austrian Government, „International and Comparative Law Quarterly” 2000, vol. 49, $\mathrm{nr} 4$.

Izdebski M., Unijny mechanizm ochrony praworządności w państwach członkowskich, „Prawo Europejskie w Praktyce" 2016, nr 4.

Kochenov D., Pech L., Monitoring and Enforcement of the Rule of Law in the EU: Rhetoric and Reality, „European Constitutional Law Review” 2015, nr 3.

Lankosz K. (red.), Traktat o Unii Europejskiej. Komentarz, C.H. Beck, Warszawa 2003.

Lenaerts K., The Court of Justice and National Courts: A Dialogue Based on Mutual Tryst and Judicial Independence, wystąpienie w Naczelnym Sądzie Administracyjnym w Warszawie, 19 marca 2018 (manuskrypt w posiadaniu autorki).

Łętowska E., Zmierzch liberalnego państwa prawa w Polsce, „Kwartalnik o Prawach Człowieka" 2017, nr 1-2.

Marcisz P., Taborowski M., Nowe ramy Unii Europejskiej na rzecz umocnienia praworzadności. Krytyczna analiza analizy krytycznej (artykut polemiczny), „Państwo i Prawo” 2017, nr 12.

Matczak M., The Strength of the Attack or the Weakness of the Defence? Poland's Rule of Law Crisis and Legal Formalism, DOI:10.2139/ssrn.3121611.

Pech L., Platon S., Systemic Threats to the Rule of Law in Poland: Between Action and Procrastination, „European Issues” 2017, $\mathrm{nr} 451$.

Sadurski W., Adding Bite to Bark: The Story of Article 7, EU Enlargement, and Jörg Heider, „Columbia Journal of European Law” 2010, nr 16.

Taborowski M., CJEU Opens the Door for the Commission to Reconsider Charges against Poland, Verfassungsblog, 2018/3/13, DOI: 10.17176/20180313-203040.

Würtenberger T., Tkaczyński J., Nowe ramy Unii Europejskiej na rzecz umocnienia praworzadności (analiza krytyczna), „Państwo i Prawo” 2017, nr 9.

Wyrzykowski M., ,Wrogie przejęcie” porządku konstytucyjnego, w: M. Bernat i in. (red.), Wyzwania dla ochrony konkurencji i regulacji rynku, C.H. Beck, Warszawa 2017. 